\title{
Vegetative and reproductive phenology of Butia purpurascens Glassman (Arecaceae) under the effects of leaf harvesting
}

\author{
Guilherme, FAG. ${ }^{a *}$, Vasconcelos, EI. ${ }^{a}$, Coelho, CP. ${ }^{a}$, Ressel, K. ${ }^{a}$, Batista, NTFa and Souza, LF. ${ }^{a}$ \\ a'Unidade Jatobá, Universidade Federal de Goiás - UFG, BR 364, Km 192, Regional Jataí Parque Industrial, \\ CEP 75801-615, Jataí, GO, Brazil \\ *e-mail: fredericoagg@gmail.com
}

Received: May 10, 2013 - Accepted: January 16, 2014 - Distributed: March 31, 2015

(With 4 figures)

\begin{abstract}
Butia purpurascens is an endemic and threatened palm tree species that occurs in open areas of the Brazilian Cerrado, predominantly in southwestern Goiás. The leaves of this palm tree are harvested by local people to fabricate brooms. This study evaluated changes in vegetative and reproductive phenology in two different natural populations of this palm tree: one population with leaf harvesting and another non-harvested population. Twenty plants were monitored in each area for 23 months. The phenophases were related to the temperature and precipitation averages for a 30-year period. Leaf sprouting occurred throughout the year, with a slight reduction in periods of low temperatures and low rainfall. The first spathes emerged in March and flowering began during the dry season (June), continuing until January of the following year, concurrent with the period of most intense fruiting. Flowering and fruiting appear to be triggered by periods of drought, which are commonly observed in the Cerrado. The harvested sites produced significantly fewer leaves, spathes, inflorescences and infructescences than the non-harvested sites. Thus, the supply of resources to the local fauna is possibly reduced in sites under leaf exploitation, which in the long term can represent damage to the palm tree population's structure and dynamics. Other socioeconomic and ecological studies about the effects of leaf harvesting in B. purpurascens are necessary to enable strategies for sustainable use, devise management alternatives and conserve this threatened palm species.
\end{abstract}

Keywords: Brazilian cerrado, reproductive biology, threatened palms conservation, leaf extraction, non-timber forest products.

\section{Fenologia vegetativa e reprodutiva de Butia purpurascens Glassman (Arecaceae) sob efeitos da extração de folhas}

\section{Resumo}

Butia purpurascens é uma palmeira endêmica e ameaçada que ocorre em áreas de cerrado sentido restrito do sudoeste goiano e tem suas folhas extraídas pela população local para a confecção de vassouras. O estudo avaliou variações na fenologia vegetativa e reprodutiva em duas populações naturais da palmeira em Jataí, GO: uma área sem extração e outra com extrativismo foliar. Vinte indivíduos foram monitorados em cada área durante 23 meses. As fenofases foram relacionadas às medias de temperatura e precipitação por um período de 30 anos. O brotamento foliar ocorreu ao longo de todo o ano, embora tenha reduzido nos períodos de menor temperatura e pluviosidade. A emissão das primeiras espatas se iniciou em março e a floração teve início durante a estação seca (junho), perdurando até janeiro do ano seguinte, concomitante ao período de intensa frutificação. Floração e frutificação parecem ser desencadeadas por períodos de estiagem, comum no Cerrado brasileiro. Áreas com extração produziram número significativamente menor de folhas, espatas, inflorescências e infrutescências do que áreas sem extração. Assim, a oferta de recursos para a fauna local é reduzida em áreas sob extrativismo, o que pode prejudicar a estrutura e a dinâmica populacional da palmeira, em longo prazo. Outros estudos sócio-econômicas e ecológicos sobre os efeitos da extração foliar em B. purpurascens são necessários para permitir estratégias de exploração sustentável, alternativas de manejo e a conservação dessa espécie atualmente ameaçada.

Palavras-chave: Cerrado, biologia reprodutiva, conservação de palmeiras ameaçadas, exploração foliar, produtos florestais não madeireiros. 


\section{Introduction}

The world's population satisfies a considerable part of its subsistence requirements through the exploitation of Non-Timber Forest Products (NTFPs), with more than 4000 species used for commercial purposes (Iqbal, 1993; Ticktin, 2004). In most cases, the ecological impacts of harvesting these species are unknown, despite the interest in NTFPs for sustainable use and maintaining biodiversity. This has led to discussions about exploring the value of these products for conservation and about the socioeconomic well-being of the rural populations and/or people with reduced purchasing power who exploit them (Arnold and Ruiz Pérez, 2001; Pattanayak and Sills, 2001).

The large number of species suppliers of NTFP, the variety of exploited plant parts, the considerable differences in the patterns and intensities of logging and also the short-term scale used in many previous studies, make generalizations about the ecological impact of NTFP exploitation difficult to measure (Ticktin, 2004). The use of leaves is one type of extraction for which short-term studies may be inadequate to assess the long-term effects of the harvesting activity. This is because harvesting the leaves may not result in the death of the plant species (Mendoza et al., 1987; Ratsirarson et al., 1996; Endress et al., 2004a, 2006), and the effects of harvesting tend to be cumulative over time.

The leaves of many species are used for multiple purposes. Specifically in the Arecaceae family, several species are used by rural populations. Their leaves are extracted for different aims, including brooms, thatch roofs, baskets and other commercial and craft uses (Lorenzi et al., 2010). In Brazil, there are several examples of savanna and forest formations that are dominated by palm species, such as the babaçu (Attalea speciosa Mart.) and the açaí (Euterpe oleracea Mart. and Euterpe precatoria Mart.) in the Amazon watershed, the juçara-palm (Euterpe edulis Mart.) in the Atlantic Rainforest, and the buriti (Mauritia flexuosa L.) in the wet grasslands of the Brazilian Cerrado. All these species are important to the country from the economic extraction aspect. Therefore, the palms stand out both by virtue of the natural and economic resources they render to human populations, and also by their ecological role in the phytophysiognomies where they occur (Peres, 1994). Furthermore, they promote food for many seed dispersers (Galetti et al., 1992; Brewer, 2001; Henderson 2002) and suitable sites for nesting. Information about their age, structure, regeneration, survival, and mortality, in addition to studies on phenological patterns and other aspects of reproductive biology of palm populations, are important for the evaluation of this resource supply and for the management and conservation of exploited species.

Studies show that palm leaf harvesting generally increases the rate of leaf sprouting (Mendoza et al., 1987; O'Brien and Kinnaird, 1996; Anten et al., 2003; Endress et al., 2004b), although this tends to decrease the size of the new leaves (O'Brien and Kinnaird, 1996; Ratsirarson et al., 1996; Endress et al., 2004b, 2006). With regard to reproductive aspects, several studies have found a reduction in the production of inflorescences and a decrease in the number of reproductive individuals in palm populations under leaf extraction pressure (Ratsirarson et al., 1996; Flores and Ashton, 2000; Anten et al., 2003; Endress et al., 2004a; Martinez-Ramos et al., 2009).

Butia purpurascens Glassman is an endemic palm found in open areas of the Brazilian Cerrado, occurring predominantly in the southwestern part of Goiás state. It is a threatened species due to its narrow distribution, the accelerated destruction of its natural habitat and agribusiness activities in this region. Its leaves are used to fabricate brooms, providing alternative money resources for many low-income families, especially in Jataí, one of the largest cities in the region, with approximately 90,000 inhabitants. According to reports of the harvesters, plants undergoing periodic leaf removal emit fewer inflorescences than those not undergoing extraction. However, studies to assess the ecological and socioeconomic importance and potential demographic effects of leaf harvesting on natural populations of $B$. purpurascens are practically nonexistent (Guilherme and Oliveira, 2011).

Throughout its distribution range there are no Conservation Units that can ensure the long-term maintenance of this species. Allied to this, southwest Goiás makes a significant contribution to national agricultural production, especially in the form of cattle farms, corn and soybeans crops and also the imminent introduction of sugar cane crops. In this context, the current and future perspective is one of great human pressure on biodiversity in this region, especially for species with restricted distribution like $B$. purpurascens. Thus, evaluating the effects of periodic leaf removal on these palm populations can provide important insights for the continuity of this socioeconomic activity in this region, besides providing knowledge about the demographic situation of this species.

This study aimed to evaluate the vegetative and reproductive phenology of $B$. purpurascens and correlate the phenophases with the climate. Moreover, we comparatively evaluated the phenology of this palm between leaf harvested sites and non-harvested sites, in order to obtain data to contribute to the maintenance of both ecologically and economically viable populations of the species. Based on information available in the literature for several Neotropical palm species, we hypothesize that plants undergoing leaf harvesting produce less inflorescences and therefore fewer fruits.

\section{Methods}

\subsection{Species description}

Butia purpurascens occurs in grassland and savanna phytophysiognomies with well-drained soils and sparse trees on the Brazilian Cerrado (sensu Ribeiro and Walter, 2008). It is also found in pastures and gallery forests and cerradões boundaries. The species has a restricted distribution in the southwest of the state of Goiás, with the centre of this range in the city of Jataí, where shows visible high plant density (Guilherme and Oliveira, 2011). Although there are occasional records in surrounding regions, as in Triângulo Mineiro and in Mato Grosso do Sul, the species is known locally as 'palmeira-jataí' or 'coquinho-azedo'. 
Generally, adult plants have a single stipe $3-4 \mathrm{~m}$ in height, although some plants can get up to $7 \mathrm{~m}$. According to records of the local rural population and personal observations, the population of B. purpurascens is denser in open sites with sparse woody vegetation. The species has strongly arched leaves, petiole and rachis without thorns (Lorenzi et al., 2010). The plant is monoecious with male and female flowers in the same inflorescence, as in all species of the genus (Henderson et al., 1995). The fruits are ovoid with a colour ranging from yellow to wine and a juicy and aromatic mesocarp, much appreciated by the local fauna and by humans (Lorenzi et al., 2010). Fruiting occurs at the beginning of the rains, and the local population uses its fruits in regional cuisine. The species also has morphological features that provide desirable ornamental effects, an important factor that can be exploited to contribute to its conservation.

\subsection{Study sites}

The phenology was monitored in two remnants of cerrado sensu stricto close to the perimeter of Jataí City. At the first site, the owner allows harvesting of palm leaves for the purpose of fabricating brooms. This area is located on a particular property (Lajeado Farm - $17^{\circ} 53^{\prime} \mathrm{S}$ and $51^{\circ}$ $38^{\prime} \mathrm{W}$ ) and during the study period four extraction events were recorded. In addition, prior to the beginning of the evaluation, evidence of extraction was observed by traces of cutting on the leaf petioles. The second site is located in a protected area free of harvesting (41st Military Force $17^{\circ} 53^{\prime} \mathrm{S}$ and $51^{\circ} 41^{\prime} \mathrm{W}$ ). Both have obvious disturbances, such as an infestation by invasive grasses and fire marks on the tree trunks. Lajeado Farm constitutes a denser cerrado than the Military Force site, with respective densities of 1379 and 880 woody plants per hectare (FAG Guilherme, unpublished data).

The sites are approximately $6.3 \mathrm{~km}$ distant from each another and have the same climatic conditions. The climate is seasonal, classified as Awa, tropical savanna and mesothermal (by Köppen climate classification), with rainfall in the summer and dry periods in the winter (Mariano and Scopel, 2001). The average annual rainfall is $1632 \mathrm{~mm} . \mathrm{yr}^{-1}$, with maximum rainfall during December and January. However, the rainy season begins in October and extends until early April. The dry season occurs from May to August, with the minimum temperatures occurring in June and July. Relative humidity reaches its minimum in August (Figure 1), characterizing the known dry season in the central plateau of the Brazilian Cerrado. The data on temperature, humidity and rainfall were obtained from the National Institute of Meteorology (INMET), at the Jataí Station, $670 \mathrm{~m}$ above sea level.

The soils feature Dark- Red Oxisoils, which occur in the contact zone between the tertiary cover and Bauru Group sandstone. Purple Oxisoils, which occur near the Claro River, the main watercourse in the region and an important tributary of the Paranaíba river, both in the Paraná watershed, are also registered.

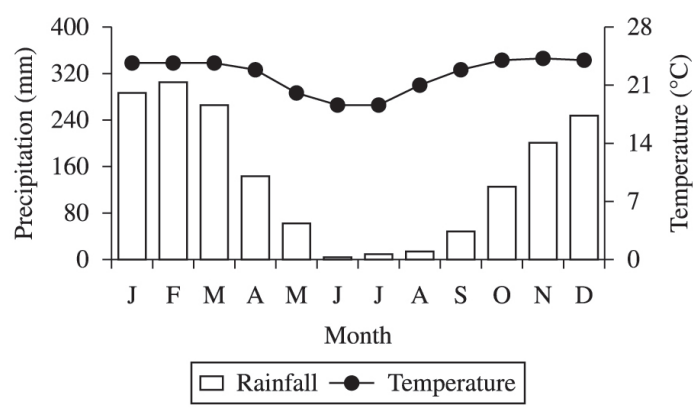

Figure 1. Annual distribution of rainfall and temperature in the city of Jataí, state of Goiás. The monthly averages were obtained from a 30-year period (1980-2009).

\subsection{Phenological evaluation and data analysis}

In each study site, 20 adult plants of $B$. purpurascens were randomized selected in one hectare sample plot. The palms were marked with numbered aluminum tags. Since the plants occur in open areas and they present small sizes, the phenological records were made directly in the sample fields, observing the phenological phases in each sample plant.

The vegetative and reproductive palm phenology was monthly evaluated over 23 months, from September 2007 to July 2009. It was observed the timing, frequency and duration of the phenological events. The phenophases were defined as follows: 1. Budding: issuance of leaf buds; 2 . Flowering beginning: spathe issuance until the inflorescence exposure; 3 . Male flowers: period of male floral anthesis; 4. Female flowers: period of female flowers anthesis until the stigma oxidation; 5. Unripe fruits: infructescenses with most of the fruits with bracts, covering less than $50 \%$ of the fruit surface until the fruit ripening; 6 . Ripe fruits: infructecenses with most of the fruits with color changing (from greenish to yellow or wine) until its complete abscission. The phenological patterns were evaluated by the presence or absence qualitative method of each phenophase (activity index), to indicate the proportion of individuals expressing a certain phenological event (D'eça-Neves and Morellato, 2004). The phenograms were developed based on the percentage of individuals in a given phenophase.

At three month intervals, the petioles of leaves surrounding the arrow leaf (new leaves set, interlaced in the plant apical growth center) were labeled with a colored thread, making possible to observe and quantify the leaves number that are produced by each plant in each site.

The phenophases were related with climatic variables, using the temperature and precipitation averages, referring to the monthly temperature and precipitation averages for a 30 years period, between the years 1980-2009. As the plants may have delayed a phenological response to a particular environmental impulse (Marques et al., 2004), the phenological data were correlated with the climatic data from one to three months before the field observations, besides the month of each phenophase occurrence. 
Spearman correlation analysis $\left(r_{s}\right)$ was performed to determine possible relationships between climatic variables and the phenology of $B$. purpurascens. To compare the means of leaves production, female inflorescences, unripe and ripe fruits, between the sites, a $t$ test was used. Male inflorescences were not compared because this event has not been registered sometimes, and due to their duration that lasted less than one month.

Despite the two sites being assessed monthly, timely observations in four other sites were made to increase the reliance of information and to quantify the real effect of the leaf harvesting in the reproductive phenological events of $B$. purpurascens. For this, two harvesting sites (municipalities of Jataí and Caçu) and two non-harvesting sites (municipalities of Aparecida do Rio Doce and Perolândia) were selected. Twenty reproductive adult palms were randomly chosen in each site and had the spathes emission and inflorescences recorded in August 2009 , and the infructescenses assessed in November 2009. In this case, the emission stages of male and female flowers, the number of immature and mature fruits were not differentiated.

\section{Results}

\subsection{B. purpurascens phenology and climate relationships}

After nearly two years of evaluation, B. purpurascens showed an annual cycle, with reproductive events starting in March, marked by the appearance of the first spathes, and ending with fruit maturation and dispersion in January. The inflorescences showed development and anthesis progressing from the extremity to the centre of the rachilla. The male flowers occur at the apex and open first, while the female flowers are located at the base of the rachilla and expose their stigmas after senescence of the male flowers. Therefore, the species has protandry dichogamy. We observed several immature fruits dropped by many plants during their development, indicating abortive events.

Both temperature and precipitation in the month of occurrence as well as in the preceding month showed significant positive correlations with the intensity of budding (Table 1). Thus, the higher the temperature and amount of rainfall in the month before and during the month in which phenophase occurs, the greater the intensity of leaf emission. Moreover, there was a reduction in the leaf emission during the months of greatest drought and lowest temperatures (June and July).

The appearance of spathes showed an opposite tendency to that for budding. The temperature and rainfall in the month of occurrence had significant negative correlations with the onset of the reproductive phase. In the month prior to the event, only the temperature exhibited a significantly different correlation (Table 1). Thus, December, January and February have the highest average monthly temperature and precipitation, corresponding to the months of lowest spathes emission. Female floral anthesis showed no relationship with the climate; however, the strongest negative correlations with rainfall and temperature occurred between two and three months before this phenophase event (Table 1).

Fruiting began in June, with the recording of the first immature fruits in infructescenses. The fruiting periods of B. purpurascens also showed negative correlations with rainfall and temperature, although the relations of cause and effect occurred with an interval of three months. Accordingly, the climate in May and June were the most negatively correlated with fruiting events, which began maturing in August (Table 1).

\subsection{Leaf harvesting effects in B. purpurascens phenology}

The number of leaves produced was significantly different between the two sites $(t=2.30, \mathrm{df}=19$, $\mathrm{P}=0.019$ ), with the harvested and non-harvested sites, respectively, yielding an average of 1.5 and 2.5 leaves. month $^{-1}$. plant ${ }^{-1}$ (Table 2). Throughout the study, 534 and 672 leaves were emitted at the harvested and non-harvested sites, respectively. In August 2008, there was a marked increase in leaf production and the non-harvested site had a greater production than the harvested site (Figure 2a). In November 2007 there was a leaf emission peak at both sites, while May recorded a decrease in leaf production at the non-harvested site. From December 2008 to May 2009 there was again a new peak of leaf emission at the two sites (Figure 2a). We also recorded leaf extraction at the harvested site during January and June 2008, and March

Table 1. Spearman's correlations $(r)$ between phenophases $v s$. temperature $\left({ }^{\circ} \mathrm{C}\right)$ and rainfall $(\mathrm{mm})$.

\begin{tabular}{|c|c|c|c|c|c|c|c|c|}
\hline \multirow{2}{*}{ Phenofase } & \multicolumn{2}{|c|}{ Climate 0} & \multicolumn{2}{|c|}{ Climate 1} & \multicolumn{2}{|c|}{ Climate 2} & \multicolumn{2}{|c|}{ Climate 3} \\
\hline & ${ }^{\circ} \mathrm{C}$ & $\mathbf{m m}$ & ${ }^{\circ} \mathrm{C}$ & $\mathbf{m m}$ & ${ }^{\circ} \mathrm{C}$ & $\mathbf{m m}$ & ${ }^{\circ} \mathrm{C}$ & $\mathrm{mm}$ \\
\hline Budding & $0.74 * *$ & $0.64 *$ & $0.75 * *$ & $0.59 *$ & $0.52^{\mathrm{ns}}$ & $0.20^{\mathrm{ns}}$ & $0.11^{\mathrm{ns}}$ & $-0.15^{\mathrm{ns}}$ \\
\hline $\begin{array}{l}\text { Flowering beginning } \\
\text { (spathes) }\end{array}$ & $-0.91 * * *$ & $-0.88 * * *$ & $-0.72 * *$ & $-0.55^{\mathrm{ns}}$ & $-0.36^{\mathrm{ns}}$ & $-0.13^{\mathrm{ns}}$ & $0.06^{\mathrm{ns}}$ & $0.41^{\mathrm{ns}}$ \\
\hline Female flowers & $-0.13^{\mathrm{ns}}$ & $-0.51^{\mathrm{ns}}$ & $-0.66 *$ & $-0.80 * *$ & $-0.95 * * *$ & $-0.90 * * *$ & $-0.89 * * *$ & $-0.76 * *$ \\
\hline Unripe fruits & $0.41^{\mathrm{ns}}$ & $-0.05^{\mathrm{ns}}$ & $0.00^{\mathrm{ns}}$ & -0.44 ns & $-0.55^{\mathrm{ns}}$ & $-0.72 * *$ & $-0.89 * * *$ & $-0.83 * * *$ \\
\hline Ripe fruis & $0.56^{\mathrm{ns}}$ & $0.22^{\mathrm{ns}}$ & $0.29^{\mathrm{ns}}$ & $-0.15^{\mathrm{ns}}$ & $-0.19^{\mathrm{ns}}$ & $-0.50^{\mathrm{ns}}$ & $-0.68 *$ & $-0.71 * *$ \\
\hline
\end{tabular}

Climate 0 : corresponds to the month of occurrence of phenological events. Climate 1: one month prior to the event. Climate 2: two months prior to the event. Climate 3: three months prior to the event. ns: non-significant, $* P<0.05$, ** $P<0.01, * * * P<0.001$. 
Table 2. General data comparing budding, spathes production, flowering and fruiting between nonharvesting (41st Military Force) and harvesting (Farm Lajeado) site.

\begin{tabular}{lcc}
\hline & Nonharvesting & Harvesting \\
\hline Mean of leaves & $30.5 \pm 17.3$ & $24.2 \pm 12.3$ \\
Mean of spathes production & $14.3 \pm 13.4$ & $4.8 \pm 7.9$ \\
Mean of inflorescences with female flowers & $5.2 \pm 5.9$ & $1.6 \pm 2.4$ \\
Mean of infructescences with unripe fruits & $10.8 \pm 14.5$ & $2.0 \pm 3.3$ \\
Mean of infructescences with ripe fruits & $3.5 \pm 5.2$ & $0.5 \pm 1.0$ \\
\hline
\end{tabular}

All means $( \pm$ SD) were significantly different according $t$ test, for $5 \%$ probability. The $t$ test values, degrees of freedom and probability are presented in the text.
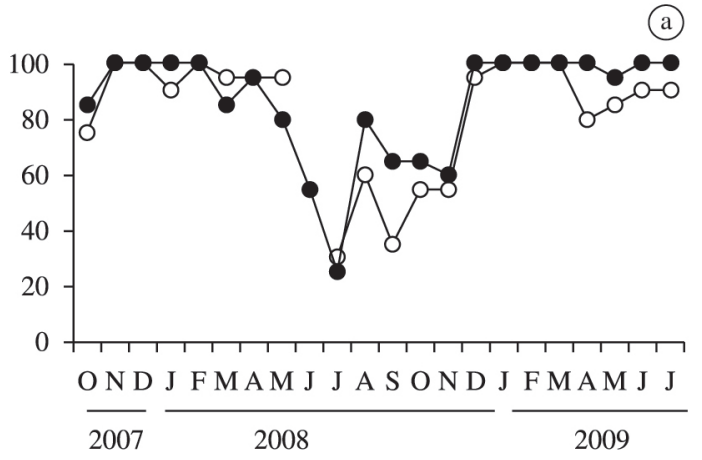

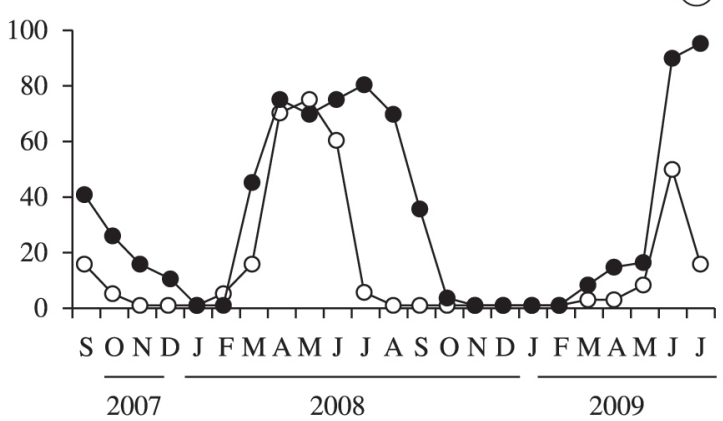

Figure 2. Comparative phenogram of monthly percentage of leaves (a) and spathes (b) issued to 20 plants in each study site. Empty circles correspond to the harvesting site and filled circles, nonharvesting site.

and June 2009. In June 2008 it was not possible to analyse the number of leaf buds, since all cutting traces were lost.

The reproduction of $B$. purpurascens began in March in both 2008 and 2009, when the first spathes arose. The emission peak happened at the end of the rainy season (May 2008 ) at the harvested site, with $75 \%$ of plants showing spathes. In 2009 , during the same period, only $7 \%$ of plants showed spathes, and in July of the same year the index reached $50 \%$, less than the peak observed in the previous year (Figure 2b). However, at the non-harvested site, the peak occurred in July 2009, with $95 \%$ of individuals developing spathes. In 2008, the peak occurred in June, with $80 \%$ of individuals presenting this phenophase, although the spread of spathes emission was similar for both sites and production was significantly higher $(\mathrm{t}=3.86, \mathrm{df}=20$, $\mathrm{P}<0.001)$ at the non-harvested site (325 in total) than at the harvested site (111) (Table 2). The greatest difference occurred in July 2008, when the non-harvested site showed 35 spathes distributed among 20 evaluated individuals, against only two spathes at the harvested site.

Male floral anthesis in the inflorescence is a short event that lasts 8-17 days, a shorter period than the monthly interval between phenological observations. Therefore, many records were lost, making it impossible to compare this phenophase between the sites, and more accurate assessments and phenograms have not been made. However, female floral anthesis occurred over a period greater than 30 days, covering the months from June to January. Significant differences were recorded between the sites $(\mathrm{t}=3.34, \mathrm{df}=20, \mathrm{P}<0.001)$. At the harvested site, we recorded 26 inflorescences on female stage and 105 at the non-harvested site (Table 2). The greatest difference occurred in October 2008, when the non-harvested site showed 17 inflorescences with female flowers distributed among all 20 individuals, whereas there was only a single record at the harvested site (Figure 3).

As with flowering, the duration and intensity of the fruiting pattern at the non-harvested site were also significantly higher than at the harvested site, both for immature fruits $(\mathrm{t}=3.55, \mathrm{df}=20, \mathrm{P}<0.001)$ and for ripe fruits $(\mathrm{t}=2.10, \mathrm{df}=20, \mathrm{P}<0.001)$ (Table 2). In September $2007,95 \%$ of individuals at the non-harvested site showed immature fruits that remained until January. From July 2008 to January 2009 their proportion was slightly lower than in the previous year (Figure 4a). On the other hand, at the harvested site, only $45 \%$ of individuals showed immature fruits in September 2007, lasting until December. Similarly, from July to November 2008 these values were much lower than at the non-harvested site. The harvested site had maturing fruits only during November and December, with a maximum of $15 \%$ of individuals with ripe fruits in December. At the non-harvested site, 30\% of individuals showed this phenophase in September and remained until January. The peak of ripeness occurred at the end of the dry season in October (70\%) and extended up to December 2008, with $50 \%$ of the plants showing ripe fruits (Figure 4b). 
A timely assessment made at four other sites showed that all the reproductive phenophases were significantly different. The means for spathes production $(\mathrm{t}=6.23$, $\mathrm{df}=78, \mathrm{P}<0.001)$, male flowers $(\mathrm{t}=2.78$, $\mathrm{df}=78$, $\mathrm{P}<0.001)$, female flowers $(\mathrm{t}=3.32$, $\mathrm{df}=78, \mathrm{P}<0.001)$ and fruits $(\mathrm{t}=3.06, \mathrm{df}=78, \mathrm{P}<0.001)$ were significantly more plentiful at non-harvested sites than at harvested sites (Table 3 ).

\section{Discussion}

\subsection{Phenological patterns of B. purpurascens}

Leaf development by $B$. purpurascens was constant throughout the year, with a slight reduction in the dry season, especially in June and July. Likewise, reproductive events lasted almost the entire year. However, they showed a marked increase in production during defined periods,

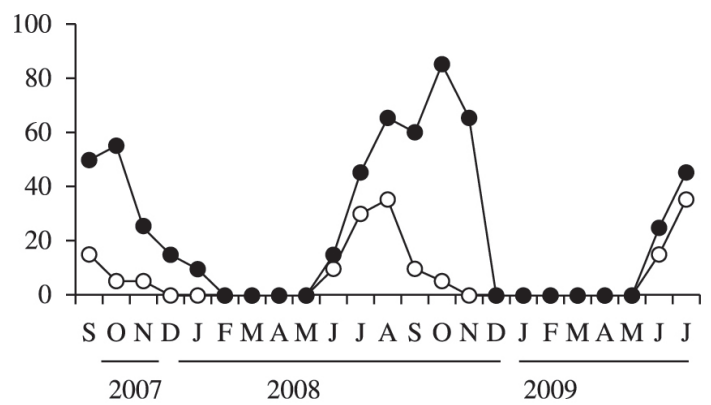

Figure 3. Phenogram of monthly percentage of female flowers on anthesis to 20 plants in each study site. Empty circles correspond to the harvesting site and filled circles, nonharvesting site. starting with spathes emergence in February, and closing the reproductive cycle in the same period of the following year when the last ripe fruits were available. Therefore, the species showed a cyclic annual reproductive pattern (sensu Newstrom et al., 1994) and a steady state according to Gentry (1974), providing some resources for wildlife fauna such as pollen, nectar, floral elements and ripe fruits throughout the entire year.

B. purpurascens starts its reproduction in the rainy season, beginning with spathes emergence, while flowering occurs specially during the dry season. Both male and female flowers open from April to May and last for about six months, so pollination events occur during this period. Although Henderson et al. (2000) did not find obvious correlations between rainfall and flowering for 27 palm species in the Amazonian watershed, low temperatures and especially less rainfall also seem to trigger blooming in palms trees in other Brazilian ecosystems, such as Euterpe in the Atlantic Rainforest (Wendt et al., 2011) and Astrocaryum in the Amazon (Piedade et al., 2006). Pollinator activity is usually more intense during the drought period (van Schaik et al., 1993), which may improve flowering success, since the reduced availability of resources increases floral visitors' faithfulness and can be essential to the maintenance of the pollinators, especially in savanna environments with pronounced seasonality (Neves and Damasceno-Junior 2011).

The fertilized female flowers of B. purpurascens started developing fruit even in the dry season. Its maturation and consequent availability for the local fauna continued until the end of January, with a peak in the transition from the dry to the wet season. Many monoecious palm species
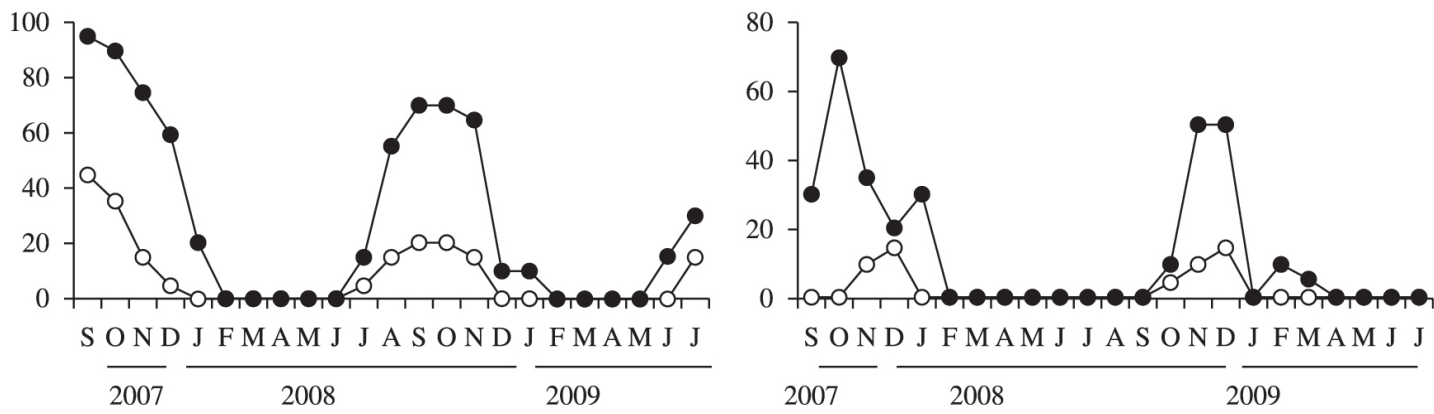

Figure 4. Comparative phenogram of monthly percentage of unripe fruits (a) and ripe fruits (b) to 20 plants in each study site. Empty circles correspond to the harvesting site and filled circles, nonharvesting site.

Table 3. General data of reproductive phenophases for other sites timely evaluated.

\begin{tabular}{lcc}
\hline & Nonharvesting $(\mathbf{n}=\mathbf{2})$ & Harvesting $(\mathbf{n}=\mathbf{2})$ \\
\hline Mean of spathes production & $2.9 \pm 0.9$ & $1.4 \pm 1.2$ \\
Mean of inflorescences with male flowers & $0.9 \pm 0.6$ & $0.5 \pm 0.6$ \\
Mean of inflorescences with female flowers & $0.9 \pm 0.6$ & $0.4 \pm 0.6$ \\
Mean of infructescences with fruits & $0.9 \pm 0.8$ & $0.4 \pm 0.6$ \\
\hline
\end{tabular}

All means $( \pm \mathrm{SD})$ were significantly different according $t$ test, for $5 \%$ probability. The $t$ test values, degrees of freedom and probability are presented in the text. 
evaluated by Henderson et al. (2000) in the Amazon also showed this pattern. This may be a strategy for further germination and seedling establishment, especially in the Brazilian Cerrado with its marked seasonality. During this period, B. purpurascens fails to allocate resources to vegetative growth in order to invest in fruiting, ensuring greater chances for the species' perpetuation.

The reproductive phenology, specially the onset of flowering, was negatively correlated with rainfall and temperature, showing different responses in the intensity of each event for the month of its occurrence and the rainfall intensity. This suggests that $B$. purpurascens has a mechanism to recognize annual periods of low humidity, and possibly the consequent decrease in the length of the day is able to trigger the reproductive phase. Other palm species in Central America also seem to start flowering late in the dry season (Steven et al., 1987; Ibarra-Manríquez, 1992), reinforcing the idea that combination of drought followed by periods of rain can promote the occurrence of these events. However, further studies in B. purpurascens are necessary to try to relate its phenological patterns with biotic factors such as pollination, dispersal, herbivory and predation. Henderson et al. (2000) argued that the vegetative and reproductive phenological patterns of species are mostly affected by endogenous aspects (physiological, nutritional, genetic, reproductive) and ecological conditions (edaphic factors, pollination, predation, competition), and not only by the influence of climatic variables.

\subsection{Leaf harvesting and ecological implications}

This study showed that leaf harvesting changed the phenological behaviour of $B$. purpurascens, causing negative impacts on leaves, flowers and fruit development at the harvested sites. This generates ecological consequences for natural populations and other organisms that depend on some of the resources provided by this species. These data are supported by Vasquez and Gentry (1989), who evaluated the harvesting of wild fruits and their impacts on natural plant populations. In Indonesia, O'Brien and Kinnaird (1996) demonstrated that an increase in the intensity of leaf harvesting reduces subsequent production of leaves by Livistona rotundifolia (Lam) Mart. Moreover, sites with intense harvesting have reduced population density. Other studies have also found negative effects of leaf extraction on the flowering and fruiting of tropical palms, such as Neodypsis decaryi Jum. (Ratsirarson et al., 1996), Geonoma deversa (Poit.) Kunth (Flores and Ashton 2000), Chamaedorea radicalis Mart. (Endress et al., 2004b, 2006) and Chamaedorea elegans Mart. (Anten et al., 2003; Martínez-Ramos et al., 2009). This reinforces the idea that leaf harvesting in B. purpurascens results in a reduced reproductive potential for individuals under extraction influence, besides reducing the extracted product, i.e. the leaves.

Natural populations of $B$. purpurascens can be directly affected in the medium to long-term, since loss of reproductive strength would lead to a decline in the population, increasing its threat of extinction. Moreover, lower reproductive strength in populations subjected to leaf extraction possibly renders the species more vulnerable to attack by pathogens and local environmental changes. Thus, any reduction in nutrient availability or a severe drought could affect the survival of plants with reduced vitality (O'Brien and Kinnaird, 1996). With constant leaf extraction, the harvesters could also suffer in the shortterm, by reducing the availability of fruits that are also used in the local gastronomy.

The low reproductive success recorded in populations of $B$. purpurascens under extraction pressure can generate a strong impact on the ecological resource supply, because the flow of seed dispersers is key to ensuring the succession process (Tabarelli et al., 2004). In addition, several palm species are potential colonizers and important for the proper functioning of the ecosystem (Peres, 1994; Henderson 2002). Therefore, the lower fruit production at harvested sites can have long-term implications for the population structure and dynamics of B. purpurascens, reducing its rates of germination and establishment, which was also noted by Flores and Ashton (2000) in Geonoma deversa. Furthermore, those populations that are free of extractive activities had broad and massive flowering and fruiting periods and may attract a larger number of pollinators and seed dispersers, maintaining the ecological balance in the natural populations.

\subsection{Sustainable harvesting as a strategy for maintaining $B$. purpurascens and other native species of the Brazilian Cerrado}

Natural populations of $B$. purpurascens show a mean of 89 adult plants.hectare ${ }^{-1}$ with exposed stipes (only these plants have their leaves extracted) according to a recent demographic study (Guilherme and Oliveira, 2011). As the current study showed that a single individual produces, on average, 14 leaves per year, we can estimate that at sites of natural palm occurrence in the southwestern state of Goiás, one hectare produces, over a year, approximately 1,240 leaves. This would allow the confection of approximately 124 straw brooms, considering that 10 leaves are necessary per broom, according to information from the regional harvesters. Whereas the value of the brooms is $\mathrm{R} \$ 4.00$, one hectare of a natural population of $B$. purpurascens can generate an annual income that can reach $\mathrm{R} \$ 500.00$. Values close to these were also calculated for Geonoma deversa, generating an income of up to 191 dollars.hectare ${ }^{-1}$.year ${ }^{-1}$ (Flores and Ashton, 2000).

However, based on information obtained from studies on other palm tree populations concerning their sustainable leaf production (Ratsirarson et al., 1996), we recommend that extraction of B. purpurascens amount to no more than one-third of the total leaves produced by each palm, equivalent to 4-5 leaves.plant ${ }^{-1}$.year ${ }^{-1}$, i.e. just over 400 leaves.hectare ${ }^{-1}$.year ${ }^{-1}$. We emphasize that for effective management design it is important to monitor these activities as a mechanism to assess the sustainability of harvest activity in the long-term and keep the practice 
of harvesting feasible, as demonstrated by Flores and Ashton (2000).

The leaf and fruit exploitation and processing of B. purpurascens associated with the use of other NTFPs and with the cultivation of other species may be able to generate income and open new possibilities for many rural families. The continuity of ecological studies related to the effects of leaf harvesting on populations of $B$. purpurascens becomes important in order to create strategies for their sustainable exploitation. The sustainable use of resources and the consequent preservation of NTFPs only occur with the engagement of the local population, the establishment of craft production units in the region, and joint efforts to link scientific and traditional harvesting knowledge (Sambou et al., 2002; Ticktin, 2004). Finally, in order to maintain the extractive activity, it is important to diversify the use of B. purpurascens palms, reducing the demand on a single resource. Joint exploitation of leaves and fruits can promote a positive impact on the establishment and propagation of the species, similar to what has been done for Butia species in Southern Brazil (Büttow et al., 2009). With such diversification of products derived from the processing of Cerrado plant species, the income raised by human populations will certainly be greater than that generated by just a single product or species.

\section{Acknowledgements}

The authors are thankful to 41st Military Force and the owner farm Lajeado, by allowing the access in study sites; to Brazilian Research Council (CNPq) for a Productivity Grant (Process number 503938/2009-2) and 'Edital Universal' (Process number 471146/2008-0) to FAG Guilherme, and the PIBIC Grant to NTF Batista and EI Vasconcelos.

\section{References}

ANTEN, NPR., MARTÍNEZ-RAMOS, M. and ACKERLY, DD., 2003. Defoliation and growth in an understory palm: quantifying the contributions of compensatory responses. Ecology, vol. 84, no. 11, p. 2905-2918. http://dx.doi.org/10.1890/02-0454

ARNOLD, JEM. and RUIZ PÉREZ, M., 2001. Can non-timber forest products match tropical forest conservation and development objectives? Ecology Economist, vol. 39, no. 3, p. 437-447. http:// dx.doi.org/10.1016/S0921-8009(01)00236-1.

BREWER, SW., 2001. Predation and dispersal of large and small seeds of a tropical palm. Oikos, vol. 92, no. 2, p. 245-255. http:// dx.doi.org/10.1034/j.1600-0706.2001.920206.x.

BÜTTOW, MV., BARBIERI, RL., NEITZKE, RS. and HEIDEN, G., 2009. Conhecimento tradicional associado ao uso de butiás (Butia spp., Arecaceae) no sul do Brasil. Revista Brasileira de Fruticultura, vol. 31, no. 4, p. 1069-1075. http://dx.doi.org/10.1590/ S0100-29452009000400021.

D'EÇA-NEVES, FF. and MORELLATO, LPC., 2004. Métodos de amostragem e avaliação utilizados em estudos fenológicos de florestas tropicais. Acta Botanica Brasilica, vol. 18, no. 1, p. 99-108. http://dx.doi.org/10.1590/S0102-33062004000100009.
ENDRESS, BA., GORCHOV, DL. and NOBLE, RB., 2004a. Nontimber forest product extraction: effects of harvest and browsing on an understory palm. Ecological Applications, vol. 14, no. 4, p. 1139-1153. http://dx.doi.org/10.1890/02-5365.

ENDRESS, BA., GORCHOV, DL., PETERSON, MB. and PADÓN SERANO, E., 2004b. Harvest of the palm Chamaedorea radicalis, its effects on leaf production, and implications for sustainable management. Conservation Biology, vol. 18, no. 3, p. 822-830. http://dx.doi.org/10.1111/j.1523-1739.2004.00073.x.

ENDRESS, BA., GORCHOV, DL. and BERRY, J., 2006. Sustainability of a non-timber forest product: effects of alternative leaf harvest practices over 6 years on yield and demography of the palm Chamaedorea radicalis. Forest Ecology and Management, vol. 234, no. 1-3, p. 181-191. http://dx.doi.org/10.1016/j. foreco.2006.07.020

FLORES, CF. and ASHTON, PS., 2000. Harvesting impact and economic value of Geonoma deversa, Arecaceae, an understory palm used for roof Thatching in the Peruvian Amazon. Economic Botany, vol. 54, no. 3, p. 267-277. http://dx.doi.org/10.1007/ BF02864781.

GALETTI, M., PASCHOAL, M. and PEDRONI, F., 1992. Predation on palm nuts (Syagrus romanzoffiana) by squirrels (Sciurus ingrami) in southeast Brazil. Journal of Tropical Ecology, vol. 8, no. 01, p. 121-123. http://dx.doi.org/10.1017/ S0266467400006210.

GENTRY, AH., 1974. Flowering phenology and diversity in tropical Bignoniaceae. Biotropica, vol. 6, no. 1, p. 64-68. http:// dx.doi.org/10.2307/2989698.

GUILHERME, FAG. and OLIVEIRA, AS., 2011. Estrutura populacional de Butia purpurascens Glassman (Arecaceae) em duas áreas de cerrado sensu stricto no estado de Goiás. Revista de Biologia Neotropical, vol. 7, no. 1, p. 37-45.

HENDERSON, A., GALEANO, G. and BERNAL, R.,1995. Field guide to the palms of the Americas. Princeton: Princeton University Press. 351 p.

HENDERSON, A., FISCHER, B., SCARIOT, A., PACHECO, MAW. and PARDINI, R., 2000. Flowering phenology of a palm community in a Central Amazon Forest. Brittonia, vol. 52, no. 2, p. 149-159. http://dx.doi.org/10.2307/2666506.

HENDERSON, A., 2002. Evolution and ecology of palms. New York: The New York Botanical Garden Press. 259 p.

IBARRA-MANRÍQUEZ, G., 1992. Fenología de las palmas de uma selva cálido húmeda de México. Bulletin Intern. Fr. Etudes Andines, vol. 21, no. 2, p. 669-683

IQBAL, M.,1993. International Trade in Non-wood Forest Products. An Overview. Rome: Food and Agricultural Organization.

LORENZI, H., NOBLICK, LR., KAHN, F. and FERREIRA, E.,2010. Flora brasileira: Arecaceae (palmeiras). Nova Odessa: Plantarum. 384 p.

MARIANO, ZF. and SCOPEL, I.,2001. Períodos de deficiências e excedentes hídricos na região de Jataí/GO. In Anais do XII Congresso Brasileiro de Agrometeorologia, 2001. Fortaleza. Fortaleza: SBA. p. 333-334.

MARQUES, MCM., ROPER, JJ. and SALVALAGGIO, APB., 2004. Phenological patterns among plant life forms in a subtropical forest in southern Brazil. Plant Ecology, vol. 173, no. 2, p. 203213. http://dx.doi.org/10.1023/B:VEGE.0000029325.85031.90. 
MARTÍNEZ-RAMOS, M., ANTEN, NPR. and ACKERLY, DD., 2009. Defoliation and ESNO effects on vital rates of an understorey tropical rain forest palm. Journal of Ecology, vol. 97, no. 5, p. 1050-1061. http://dx.doi.org/10.1111/j.1365-2745.2009.01531.x.

MENDOZA, A., PINERO, D. and SARUKHÁN, J., 1987. Effects of experimental defoliation on growth, reproduction, and survival of Astrocaryum mexicanum. Journal of Ecology, vol. 75, no. 2, p. 545-554. http://dx.doi.org/10.2307/2260433.

NEVES, DRM. and DAMASCENO-JUNIOR, GA., 2011. Postfire phenology in a campo sujo vegetation in the Urucum plateau, Mato Grosso do Sul, Brazil. Brazilian Journal of Biology, vol. 71 , no. 4 , p. $881-888$.

NEWSTROM, LE., FRANKIE, GW. and BAKER, HG., 1994. A new classification for plant phenology based on flowering patterns in lowland Tropical Rain Forest trees at La Selva, Costa Rica. Biotropica, vol. 26, no. 2, p. 141-159. http://dx.doi. org/10.2307/2388804.

O'BRIEN, TG. and KINNAIRD, MF., 1996. Effect of harvest on leaf development of the Asian palm Livistona rotundifolia. Conservation Biology, vol. 10, no. 1, p. 53-58. http://dx.doi. org/10.1046/j.1523-1739.1996.10010053.x.

PATTANAYAK, SK. and SILLS, EO., 2001. Do tropical forests provide natural resource insurance? The microeconomics of non-timber forest product collection in the Brazilian Amazon. Landscape Ecology, vol. 77, p. 595-613.

PERES, CA., 1994. Composition, density, and fruiting phenology of arborescent palms in an Amazon terra firme Forest. Biotropica, vol. 26, no. 3, p. 285-294. http://dx.doi.org/10.2307/2388849.

PIEDADE, MT., PAROLIN, P. and JUNK, WJ., 2006. Phenology, fruit production and seed dispersal of Astrocaryum jauari (Arecaceae) in Amazonian black water floodplains. Revista de Biologia Tropical, vol. 54, no. 4, p. 1171-1178. http://dx.doi. org/10.15517/rbt.v54i4.14099. PMid:18457155

RATSIRARSON, J., SILANDER, JA. and RICHARD, AF., 1996. Conservation and management of a threatened Madagascar palm species, Neodypsis decaryi, Jumelle. Conservation Biology, vol. 10 , no. 1 , p. 40-52. http://dx.doi.org/10.1046/j.15231739.1996.10010040.x.

RIBEIRO, JF. and WALTER, BMT., 2008. As principais fitofisionomias do bioma Cerrado. In SANO, SM.; ALMEIDA, SP. and RIBEIRO, JF. Cerrado Ecologia e Flora, Embrapa Cerrado. Brasília: Embrapa Informação Tecnológica. 406 p.

SAMBOU, B., GOUDIABY, A., ERVIK, F., DIALLO, D. and CAMARA, MC., 2002. Palm wine harvesting by the Bassari threatens Borassus aethiopum populations in north-western Guinea. Biodiversity and Conservation, vol. 11, no. 7, p. 11491161. http://dx.doi.org/10.1023/A:1016005025090.

STEVEN, D., WINDSOR, DM., PUTZ, FE. and LEÓN, B., 1987. Vegetative and reproductive phenologies of a palm assemblage in Panama. Biotropica, vol. 19, no. 4, p. 342-356. http://dx.doi. org/10.2307/2388632.

TABARELLI, M., SILVA, JMC. and GASCON, C., 2004. Forest fragmentation, synergisms and the impoverishment of neotropical forests. Biodiversity and Conservation, vol. 13, no. 7, p. 14191425. http://dx.doi.org/10.1023/B:BIOC.0000019398.36045.1b.

TICKTIN, T., 2004. The ecological implications of harvesting non-timber forest products. Journal of Applied Ecology, vol. 41, no. 1, p. 11-21. http://dx.doi.org/10.1111/j.1365-2664.2004.00859.x.

VAN SCHAIK, CP., TERBORGH, JW. and WRIGHT, SJ., 1993. The phenology of tropical forests: adaptive significance and consequences for primary consumers. Annual Review of Ecology and Systematics, vol. 24, no. 1, p. 353-377. http://dx.doi. org/10.1146/annurev.es.24.110193.002033.

VASQUEZ, R. and GENTRY, AH., 1989. Use and misuse of forestharvested fruits in the Iquitos Area. Conservation Biology, vol. 3, no. 4, p. 350-361. http://dx.doi.org/10.1111/j.1523-1739.1989. tb00241.x. PMid:21129022

WENDT, T., CRUZ, DD., DEMUNER, VG., GUILHERME, FAG. and BOUDET-FERNANDES, H., 2011. Investigation on reproductive isolation in sympatric populations as a tool to clarify species boundaries of Euterpe (Arecaceae). Flora, vol. 206, no. 2, p. 144-150. 